\title{
MENGAGAH HARIMAU: SENI TARI RITUAL BUDAYA MASYARAKAT PULAU TENGAH KABUPATEN KERINCI SEBAGAI IDE PENCIPTAAN SENI LUKIS SUREALIS
}

\author{
Al Ikhsan ${ }^{1^{*}}$, Asril $^{2^{*}}$, Dharsono ${ }^{3 *}$ \\ Penciptaan Seni Rupa Program Pascasarjana \\ Institut Seni Indonesia Padangpanjang \\ Jl. Bahder Johan, Guguak Malintang, Padangpanjang, Kota Padangpanjang, Kode Pos 27126 \\ Sumatera Barat. Indonesia \\ Email: ikhsanal2795@gmail.com,asril@isi-padangpanjang.ac.id,dharsono@isi-ska.ac.id
}

\begin{abstract}
Abstrak
Penciptaan karya seni ini berjudul "Mengagah Harimau: Ritual Budaya Masyarakat Pulau Tengah Kabupaten Kerinci Sebagai Penciptaan Seni Lukis Surealisme". Karya ini dilatarbelakangi oleh tari Mengagah Harimau yang tercipta dari gerak silat harimau yang diubah menjadi tarian dengan gerakan yang sama seperti gerak harimau, setelah mengamati ritual tari Mengagah Harimau, pengkarya menjadi tertarik untuk menciptakan karya lukis surealis dengan ide ritual tari Mengagah Harimau. Rancangan penciptaan tari Mengagah Harimau ini diekspresikan menjadi bentuk yang berbeda dari yang aslinya, akan tetapi tetap mempunyai unsur dan makna yang sama dengan membentuk gerak Mengagah Harimau. Desain yang akan dibuat merupakan coretan dari masing-masing tarian harimau dan disajikan ke dalam bentuk wujud lukisan dengan teknik serealis. Metode penciptaan karya seni lukis surealis ini adalah metode yang digunakan untuk mengamati sesuatu, seorang dan suatu lingkungan atau situasi secara tajam, terinci, dan mencatatnya secara akurat dalam beberapa cara yaitu observasi dan wawancara. Dari hasil wawancara, pengkarya mendokumentasikan hasil tersebut dalam bentuk foto dan rekaman. Lokasi yang dipilih sebagai sebagai objek penelitian yaitu di Desa Pulau Tengah Kabupaten Kerinci. Hasil pencipta karya seni lukis tari Mengagah Harimau ini adalah seni lukis surealisme dalam bentuk gerak pembuka, gerak mengagah, gerak membela, cakar silang, matai ateh, nak nepo, dan kemasukan imo. Bahan atau alat yang digunakan dalam penciptakan karya seni lukis surealis adalah kain kanvas, spanram, cat dasar, cat akrilik, gun stepller, dan kuas. Untuk proses penciptaan dilakukan pemasangan kain kanvas spanram, proses penggarapan karya pertama, dan proses bingkai karya. Menciptakan karya seni lukis surealisme ini bersumber dari tari Mengagah Harimau Desa Pulau Tengah Kabupaten Kerinci.
\end{abstract}

Kata Kunci: mengagah harimau, ritual tari kerinci.

\begin{abstract}
The creator of this artwork is entitled "Against the Tiger: Cultural Rituals of the Central Island Community of Kerinci Regency as the Creation of Surrealism Painting". This work is motivated by the Pengagah Harimau dance which is created from the movement of the tiger silat which is converted into a dance with the same movements as the tiger's. After observing the ritual of the Pengagah Harimau dance, the artist became interested in creating a surrealist painting with the idea of the ritual of the Pengagah Harimau dance. The design of the creation of the Pengagah Harimau dance is expressed in a different form from the original, but still has the same elements and meanings as the movement of the Menggah Harimau. The design that will be made is a scribble from each tiger dance and is presented in the form of a painting with a cereal technique. This surrealist painting creation method is a method used to observe something, a person and an environment or situation sharply, in detail, and record it accurately in several ways, namely observation and interviews. From the results of the interviews, the authors document the results in the form of photos and recordings. The location chosen as the object of research is in Pulau Tengah Village, Kerinci Regency.The result of the creator of this Menggah Harimau dance painting is surrealism painting in the form of opening motion, gazing motion, defending motion, crossed claws, matai ateh, nak nepo, and being conceded by imo. The materials or tools used in the creation of surrealist paintings are canvas, spanram, base paint, acrylic paint, gun stepller, and brushes. For the creation process, the spanram canvas is installed, the first work is done, and the work is framed. Creating this surrealism painting comes from the Menggah Harimau dance, Central Island Village, Kerinci Regency.
\end{abstract}

Keywords: enchanting tiger, kerinci dance ritual. 
Gorga : Jurnal Seni Rupa

Volume 10 Nomor 02 Juli-Desember 2021

p-ISSN: 2301-5942 | e-ISSN: 2580-2380

\section{PENDAHULUAN}

Penciptaan karya dengan judul: Mengagah Harimau: Seni Tari Budaya Masyarakat Pulau Tengah Kabupaten Kerinci sebagai Penciptaan Seni Lukis Surealisme”. Perspektif penciptaan karya seni lukis ini difokuskan pada harimau dan gerak dalam tari Mengagah Harimau, masyarakat Pulau Tengah Kerinci. Pada prosesi tersebut ada kejadian yang tidak terduga, yaitu kesurupan (kemasukan roh) harimau yang telah mati, sehingga membuat penari menjadi lepas kendali. Selain itu gerak dalam tarian Mengagah Harimau juga memiliki makna dan pesan moral yang disampaikan. Hal ini menjadi daya tarik tersendiri bagi pengkarya untuk mewujudkannya dalam bentuk karya seni lukis surealisme. Seni lukis Surealisme merupakan aliran dalam seni lukis yang erat hubungannya dengan dunia fantasi, seakan melukis dalam dunia mimpi. Lukisan surealis seringkali memiliki bentuk yang tidak logis dan seperti khayalan. Surealisme berasal dari keyakinan realitas yang superior dan kebebasan asosiasi, keserbabisaan mimpi sehingga pemikiran kita bebas kontrol dan keasdaran dalam penciptaan karya seni (Kartika, 2017: 119).

Ritual Mengagah Harimau merupakan tradisi sejak zaman dahulu. "Ngagah" dalam bahasa daerah Kerinci berarti "mengajak bermain". Tari Mengagah Harimau tercipta dari gerak silat harimau yang diubah menjadi tarian dengan gerakan yang sama seperti gerak harimau. . Tarian itu digelar saat ditemukan seekor harimau mati di hutan, dengan maksud agar gerombolan harimau tidak turun gunung dan mengganggu warga serta tidak memakan ternak warga dibayar bangun. Dengan adanya ritual adat ini, diyakini roh harimau akan mendengar dan datang memasuki tubuh si penari. Saat pertunjukan tari Mengagah Harimau banyak penonton akan dikejutkan oleh aksi kesurupan (kemasukan roh), baik para penari maupun penonton. Secara tiba- tiba sejumlah penonton berlarian ke atas panggung dan ikut menari dengan gerakan mencakar, melompat layaknya harimau.

Setelah mengamati ritual tari Mengagah Harimau, pengkarya menjadi tertarik untuk menciptakan karya lukis surealis dengan ide ritual tari Mengagah Harimau. Tari ritual Mengagah Harimau ini memiliki keunikan tersendiri dibandingkan dengan tari ritual lainnya, yaitu memiliki makna sebagai penghormatan untuk harimau yang telah mati, menonjolkan gerak silat harimau dalam gerakan tariannya, serta terdapat kejadian mistis seperti kesurupan dari penari maupun penonton yang mempunyai titisan garis keturunan dari orang Pulau Tengah Kerinci. Saat kesurupan, seseorang bisa menari/bergerak sebebas mungkin di luar dari konteks kesadarannya. Dari prosesi ritual sampai dengan gerak tari Mengagah Harimau akan menjadi inspirasi bagi pengkarya dalam menciptakan dalam berkarya rupa dengan jenis karya lukis surealis.

Rancangan penciptaan tari Mengagah Harimau ini diekspresikan menjadi bentuk yang berbeda dari aslinya namun tetap mempunyai unsur dan makna yang sama dengan membentuk gerak Mengagah Harimau . Setiap disain yang dibuat merupakan coretan dari masing-masing tari harimau. Tari Mengagah Harimau ini disajikan ke dalam wujud lukisan dengan teknik serealisme.

\section{KAJIAN TEORI}

\section{Estetika Monroe Breadsley}

Breadsley (dalam Kartika, 2016: 74) membagi estetika menjadi tiga prinsip, yaitu prinsip kesatuan, berarti bahwa benda estetis ini tersusun secara baik atau sempurna bentuknya. Prinsip kerumitan adalah benda estetis atau karya seni bersangkutan tidak sederhana sekali, melainkan kaya akan isi maupun unsur yang saling berlawanan ataupun mengandung perbedaan yang halus. Prinsip terakhir adalah kesungguhan yang merupakan suatu benda yang estetis yang baik harus mempunyai suatu kualitas tertentu yang menonjoal dan bukan sekedar sesuatu yang kosong.

\section{Surealisme}

Gagasan surealisme sesungguhnya berawal dari sastra. Sebutan ini di kemukakan oleh penyair perancis Guillaume dan di pakai untuk judul naskah di tahun 1917. Namun surealisme akhirnya lebih populer sebagai corak karya lukis.gaya surealisme kemudian lebih di dasari ilmu psiko-analisia sismud Freud, pakar psikologi awal abad 20, yang berteori tentang kesadaran dan tidak kesadaran manusia (Couto, 1999 :118). Namun disisi lain ada yang disebut dengan pop surealisme, menurut Susanto (dalam Prabu, 2017: 41) pos surealisme adalah lowbrow art yang lahir dari budaya jalanan dan komunitas jalanan.

\section{METODE PENELITIAN}

\section{Eksperimen}

Eksperimen dalam penciptaan karya seni yaitu kegiatan percobaan yang dilakukan untuk menemukan proses penciptaan yang tepat. Proses penciptaan karya yang dilakukan melalui tahap eksperimen bertujuan menemukan bahan yang tepat, teknik yang sesuai dengan konsep perancangan, alat yang mendukung. Kartika (2016: 52) mendefinisikan eksperimen sebagai berikut, eksperimen merupakan langkah kegiatan yang dilakukan seniman atau desainer dalam proses penciptaan, yang meliputi: (1) mencoba beberapa 
alternatif bahan yang sesuai dan cocok dengan ekspresi cipta seni yang dirancang, (2) mencoba beberapa alternatif teknik indivdu yang cocok dengan ekspresi dalam cipta seni yang dirancang, (3) mencoba beberapa alternatif alat yang cocok dengan ekspresi dalam cipta seni yang dirancang, dan (4) pemilihan konsep visual (tatasusun).

Percobaan di mulai dari pemilihan alat yang akan di lakukan penggarapan pemindahan sketsa ke kanvas. Sebelumnya memutuskan penggunaan alat eksperimen dalam memindahan sketsa kekanvas, pengkarya pertama mencoba dengan media garis untuk mencoba memindah kan sketsa ke kanvas, tetapi dalam eksperimen itu memakan waktu yang lama dan hasilnya tidak memuaskan dengan teknik garis.

Kemudian pengkarya mencoba untuk menggunakan invokus dalam memindahkan sketsa ke kanvas, dalam pencobaan menggunakan invokus pengkarya sangat mendah dalam memindahkan sketsa kekanvas. Hal ini pengkarya memutuskan menggunakan tekni memindahkan sketsa menggunakan media invokus.

\section{Perenungan (Riset Batin)}

Perenungan merupakan proses menggali perasaan personal untuk mengungkapkan dan mengekspresikannya ke dalam bentuk simbolik. "Perenungan merupakan penggambaran batin sang seniman dalam mencari simbol (metafora)" perenungan dilakukan untuk mencari serta menemukan simbolsimbol (bahan metafora) yang akan menjadi ikon dalam proses kreatif artistik dalam penciptaan karyaseni. (Kartika, 2016: 52).

Hasil dari prenungan dalam mengamaati riset dalam suatu bekarya dapatlah suatu desain-sain yang akan pengkarya buat, hal pertama yang harus dilakukan dalam perenungan adalah mencari inpormasi mengenai Tari Mengagah Harimau, dam mendalami tentang gerak dan simbol dari tari tersebut, selanjutnya mengambil gambar dari gerak tari yang akan di buat menjadi suatu karya seni lukis surealis.

\section{Pembentukan}

Pembentukan merupakan rancangan tatasusun atau komposisi yang dirancang untuk mendapatkan bentuk atau struktur karya" (Kartika, 2016: 54). Struktur dan bentuk karya dibuat terlebih dahulu dalam bentuk gambar, dimana gambar merupakan bahasa yang universal dan telah berkembang sebelum ditemukannya bahasa tulisan (Apriyatno dalam Halawa, 2013:6). Pembentukan sebuah karya diawali dengam ide yang dicantumkan kedalam konsep yang sedah di tulis, selanjutnya memilih photo yang akan di jadikan sketsa, yang nantinya akan menjadi sebuah Sketsa Artenatif yang dimana ide atau konsep yg dituangkan pengkarya menjadi sketsa terpilih:

Pembuka, yang berukuran 90 x $120 \mathrm{~cm}$ media yang di gunakan adala akrilik di atas kanvasakrilik mengagah, yang berukuran 100 × $120 \mathrm{~cm}$ media akrilik di atas kanvas twknik yang di gunakan surealis, membela yang berukuran 90 x $120 \mathrm{~cm}$ media yang di gunakan adala akrilik di atas kanvasakrilik,cakar silang, teknik nya sama pada karya sebelumnya yang berukuran 90 x 120 $\mathrm{cm}$ media yang di gunakan adala akrilik di atas kanvasakrilik. Matai ateh, yang berukuran 90 x $120 \mathrm{~cm}$ media yang di gunakan adala akrilik di atas kanvasakrilik. Menerkam yang berukuran 90 x $120 \mathrm{~cm}$ media yang di gunakan adala akrilik di atas kanvasakrilik. Orang kerasukan roh harimau yang berukuran 90 x $120 \mathrm{~cm}$ media yang di gunakan adala akrilik di atas kanvasakrilik.

\section{Tahap Perwujudan}

Setelah melalui beberapataham rancanagan di atas, maka dapat dilakukan suatu efaluasi secara menyeluruh untuk mengetahui ide atau konsep karya yang akan pengkarya ciptakan. Dalam penjelasan di atas yang menjadi acuan pengkarya dalam proses penciptaan Tari Mengagah Harimau menjadi suatu karya yang sangat beda tapi mempunyai arti yang sama.

\section{HASIL DAN PEMBAHASA}

\section{Hasil}

Proses perancangan karya seni meliputi pertimbangan aspek keindahan, mempunyai nilai fungsi atau kegunaan. Berikut langkah-langkah penciptaan karya:

1). Dalam proses menciptakan sebuah karya, pengkaraya pertama-tama memastikan pematangan konsep garapan yang akan pengkarya ciptakan.

2). Penggalian makna pada dari suatu prosesi ritual dan harimu. Dalam penggalian makna gerak harimau melalu wawancara ke bapak Harun sebagai penata tari dan budayawan dan pawang dari tari tersebut untuk mengetahui makna dari ritual dan simbol Tari Mengagah Harimau Pulau Tengah Kerinci.

3). Mendokumentasikan semua gerakan tentang prosesi Mengagah Harimau yang menjadi rujukan dalam berkarya rupa supaya apa yang dituangkan kedalam kanvas mudah dipahami oleh masyarakat terutama penikmat seni. 


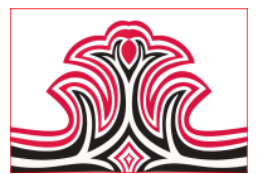

4). Di dalam berkarya rupa, pengkarya terlebih dahulu membuat coretan sketsa yang untuk di ajukan ke dosen pembimbing, untuk mendapat kan Sketsa Artenatif yang akan dituangkan kanvas dalam bentuk baru.

5). Sketsa alternatif merupakan hasil coretan atau pun ide dari pengkarya yang di cantungkan kedalam kertas ketsa sebanyak dua belas gerakan tari Mengagah Harimau, lalu di evaluasi kembali dari hasil tersebud kemudian di lakukang pemilihan sketsa-sketsa dari hasil analisi tersebut.barulah dapat hasil dari sketsa terpilih.

\section{1). Sketsa Alternatif}

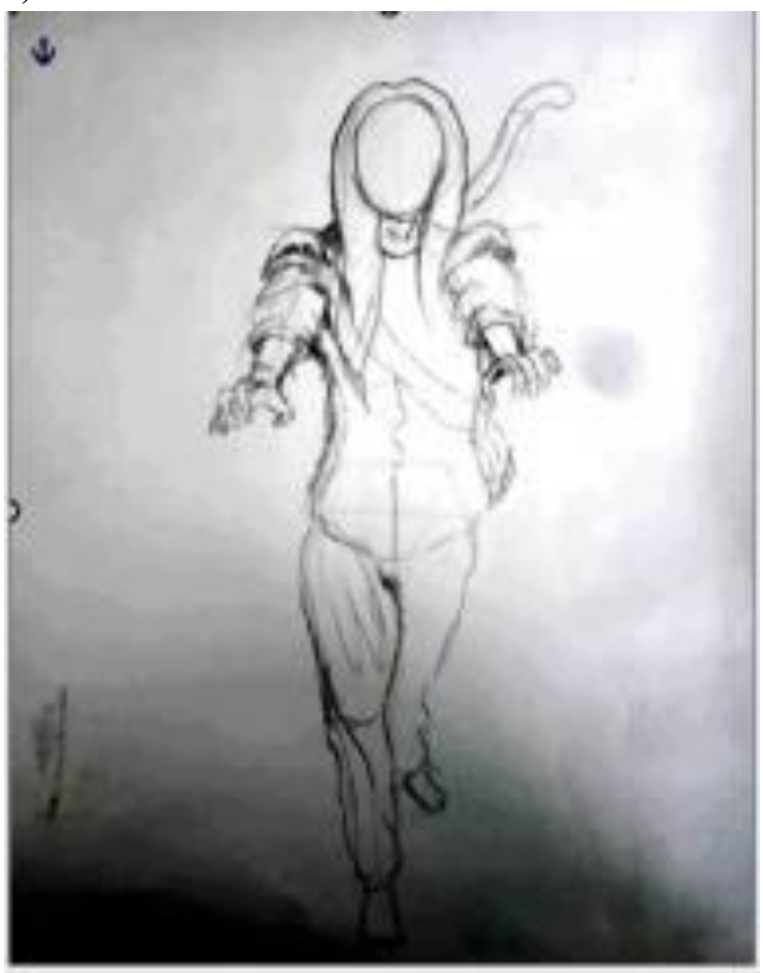

Gambar 1.

Geroak Ngageng Imo

(Gerak Mengagah Harimau)

(Ikhsan, 2021)
Gorga : Jurnal Seni Rupa

Volume 10 Nomor 02 Juli-Desember 2021

p-ISSN: 2301-5942 | e-ISSN: 2580-2380

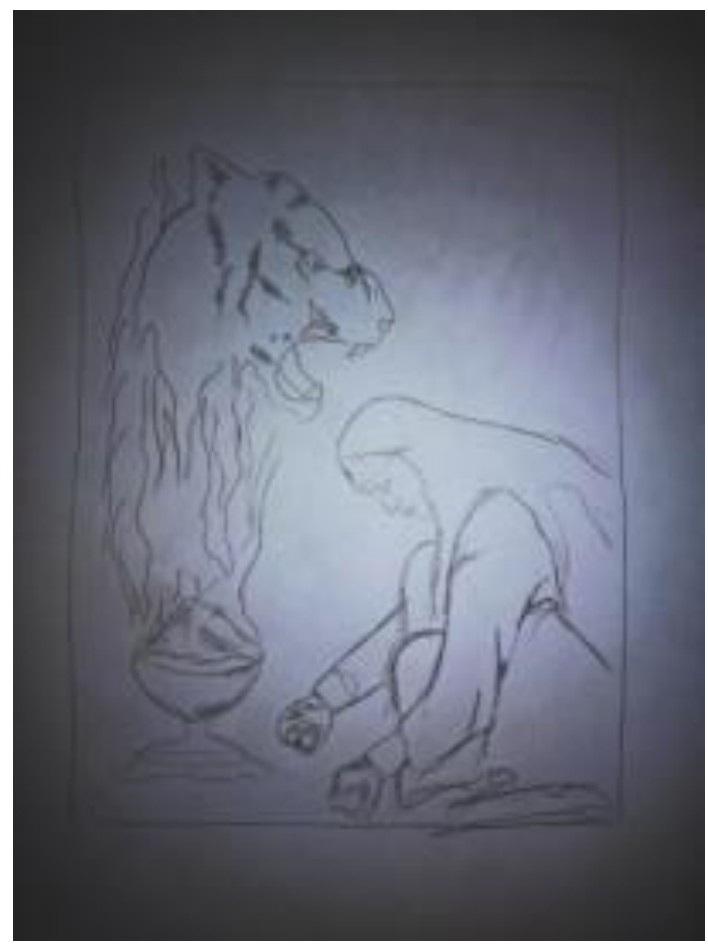

Gambar 2.

Nyerau Imo

(Memanggil Roh Harimau)

(Ikhsan, 2021)

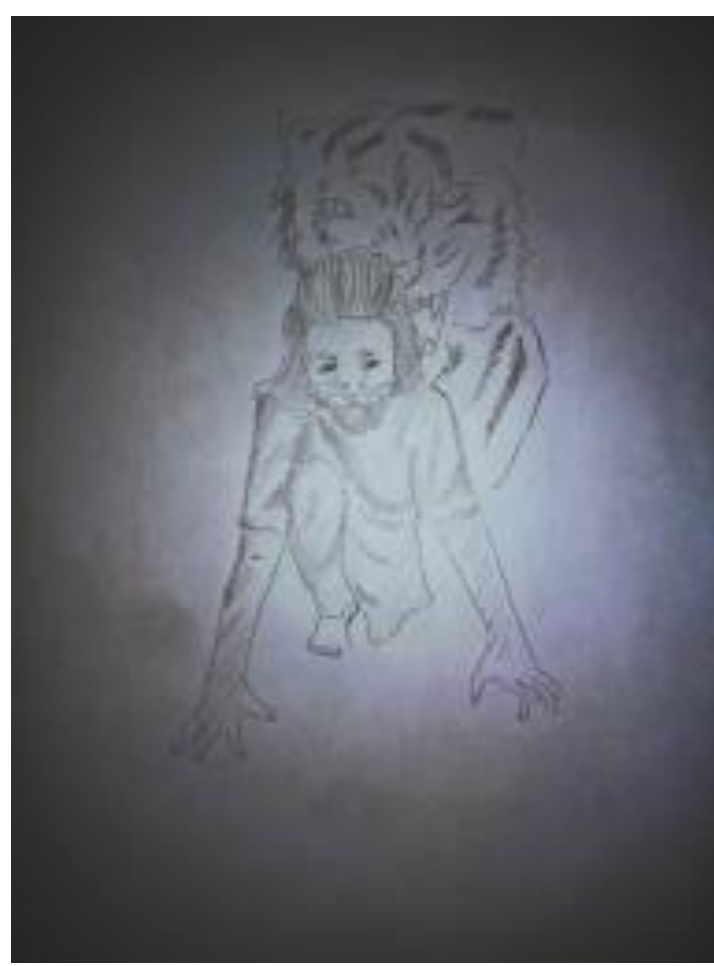

Gambar 3.

Groak Ngko Membela

(Gerak Membela)

(Ikhsan, 2021) 

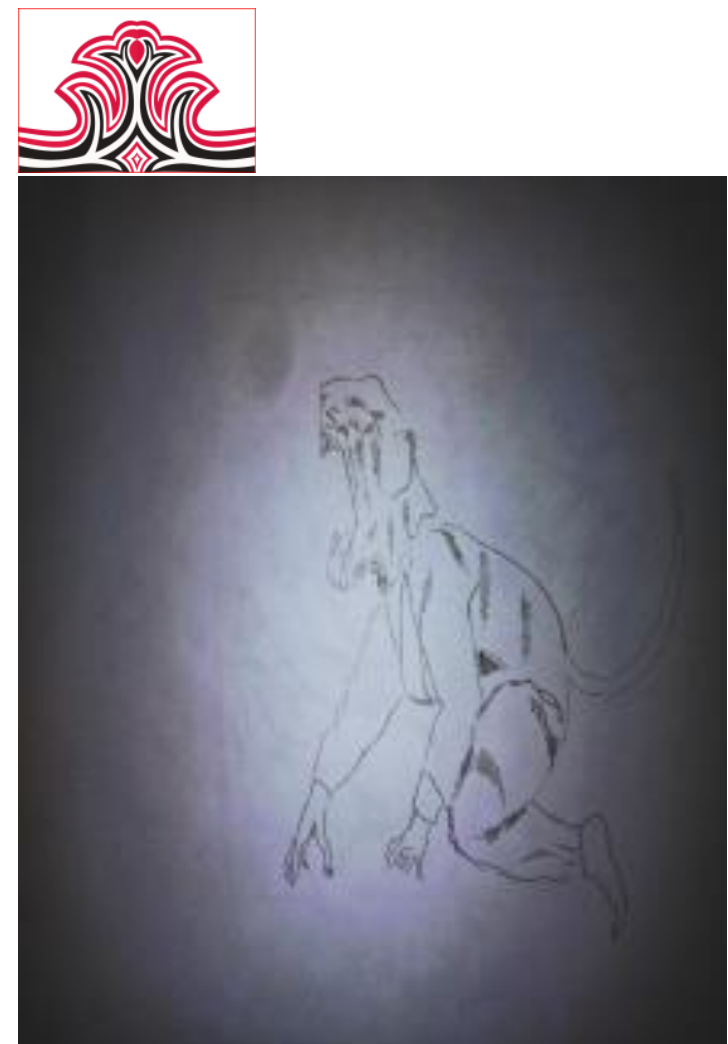

Gambar 4.

Ngko Mrawo

(Gerak Melawan)

(Ikhsan, 2021)

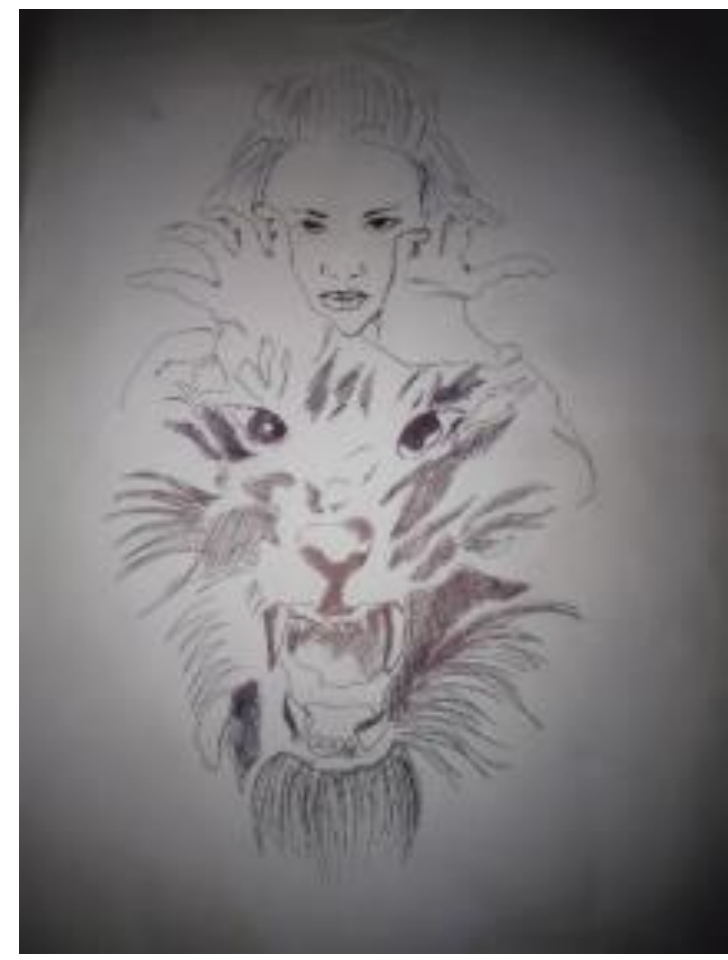

Gambar 5.

Ngko Silang (Gerak Silang)

(Ikhsan, 2021)
Gorga : Jurnal Seni Rupa

Volume 10 Nomor 02 Juli-Desember 2021 p-ISSN: 2301-5942 | e-ISSN: 2580-2380

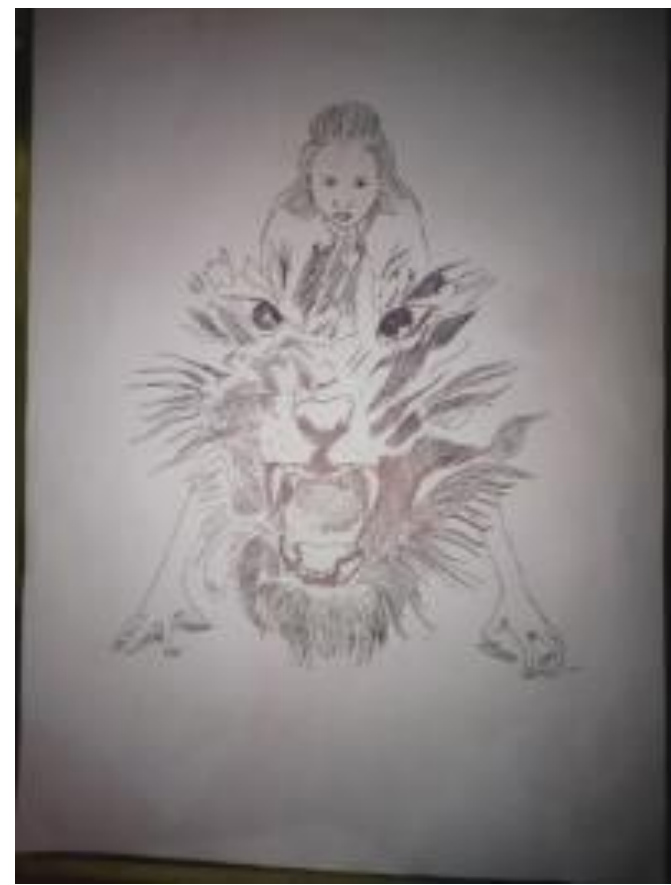

Gambar 6.

Ngko Nak Nepa

(Gerak Mau Menerkam)

(Ikhsan, 2021)

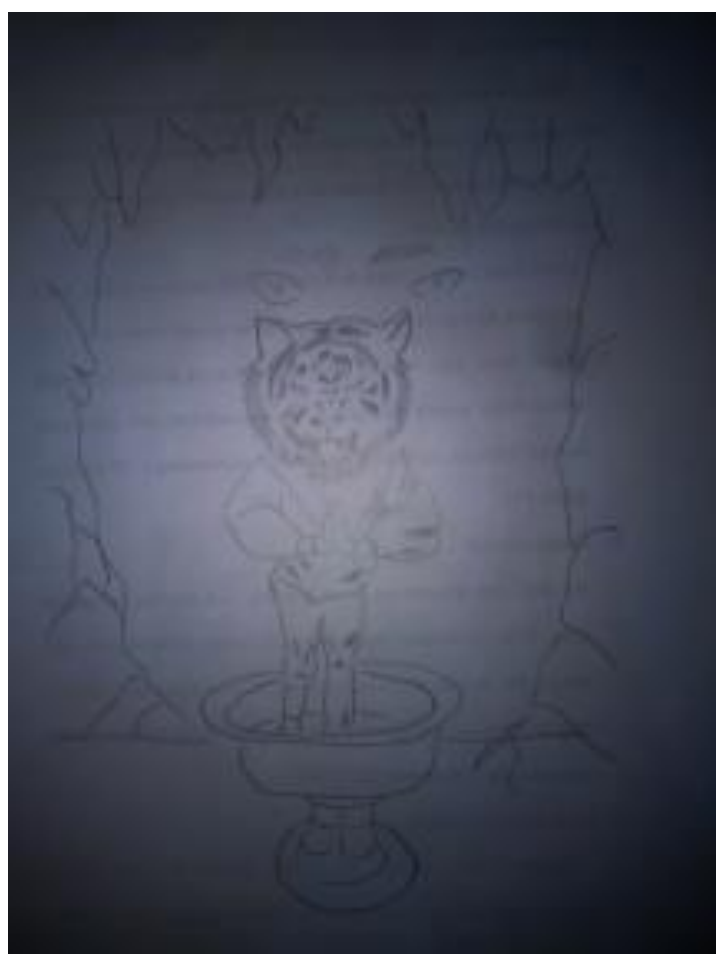

Gambar 7.

Pembukoak (Pembuka)

(Ikhsan, 2021) 

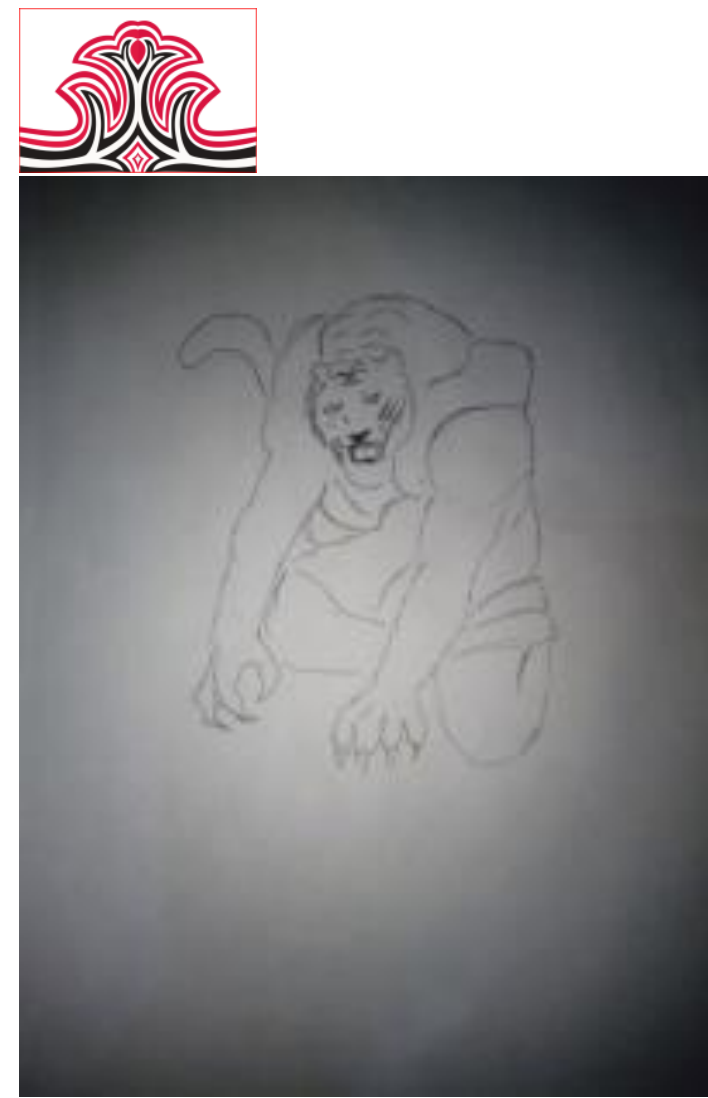

Gambar 8.

Uho Imo Masak

(Harimau Masuk Dalam Tubuh)

(Ikhsan, 2021)

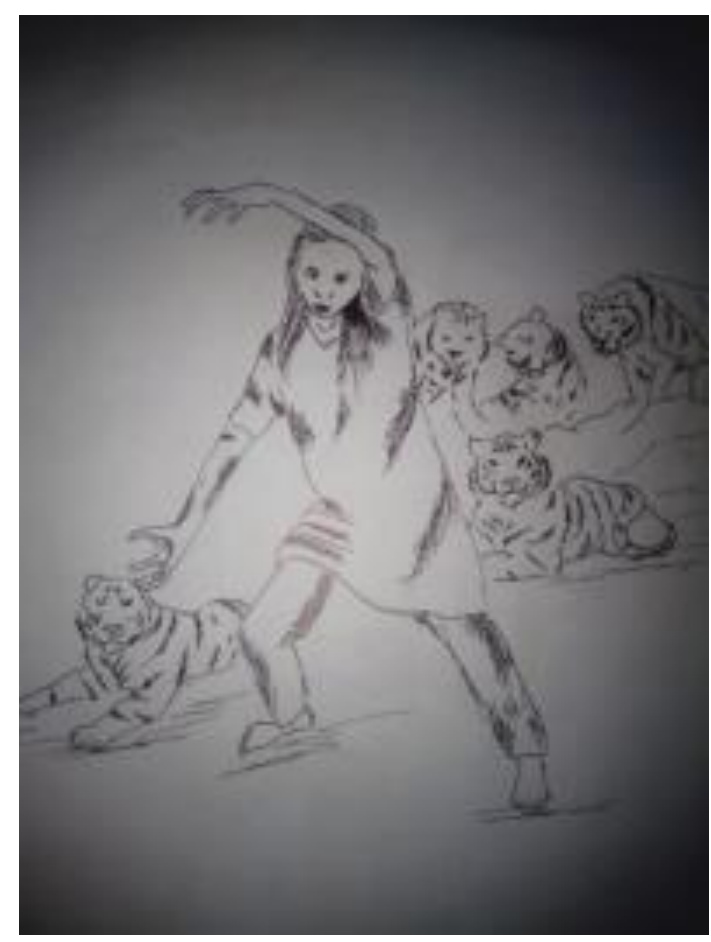

Gambar 9.

Kesamping (Silat Harimau Kesamping)

(Ikhsan, 2021)
Gorga : Jurnal Seni Rupa

Volume 10 Nomor 02 Juli-Desember 2021 p-ISSN: 2301-5942 | e-ISSN: 2580-2380

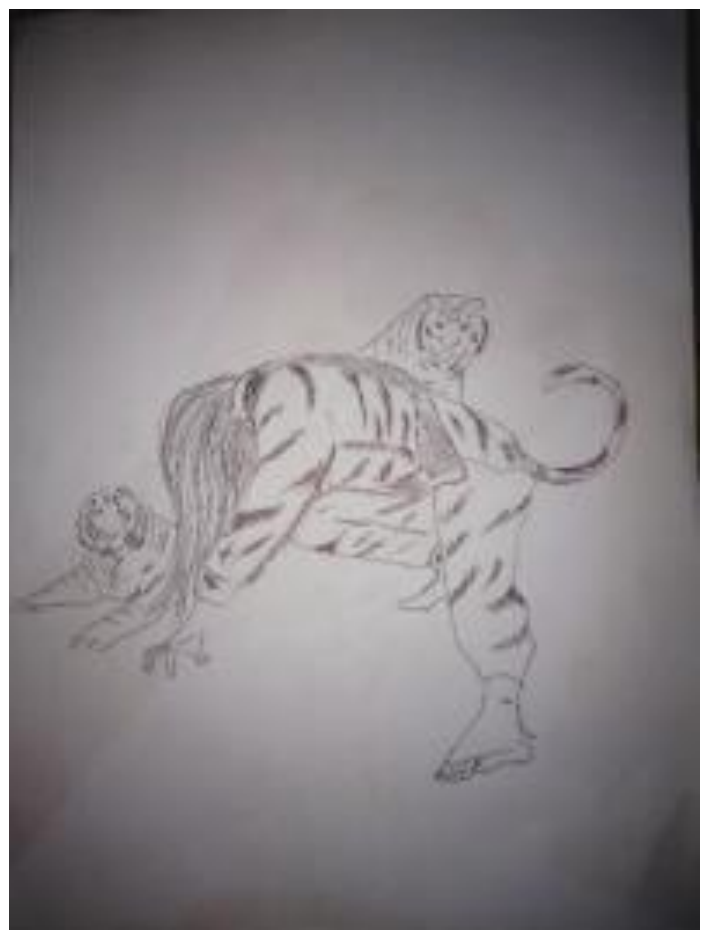

Gambar 10.

Keno Serau (Kena Serau)

(Ikhsan, 2021)

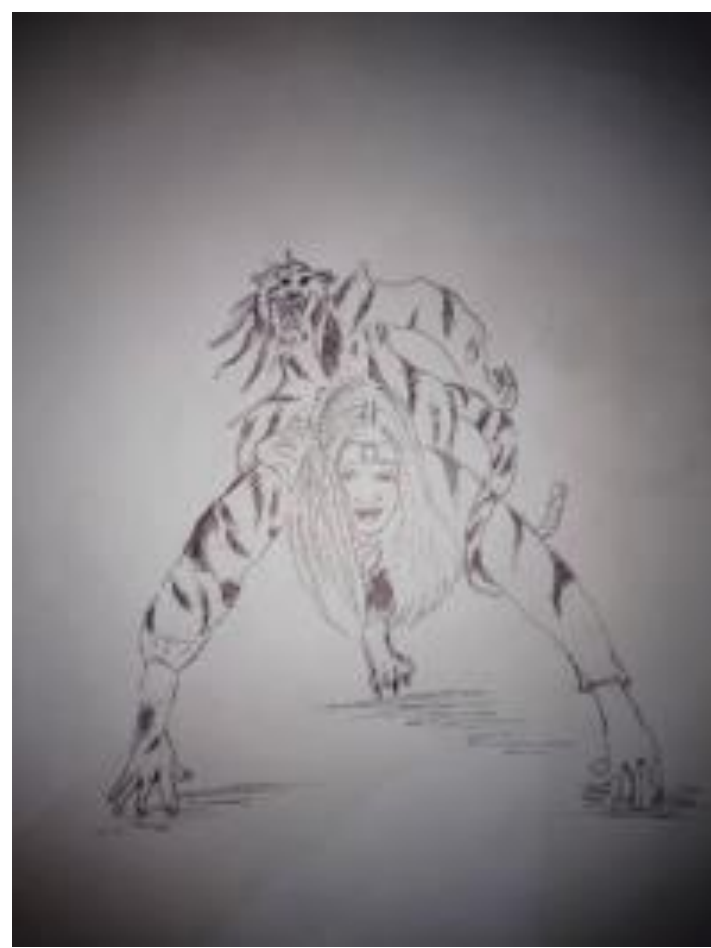

Gambar 11.

K Nak Nepo (Menerkam)

(Ikhsan, 2021) 


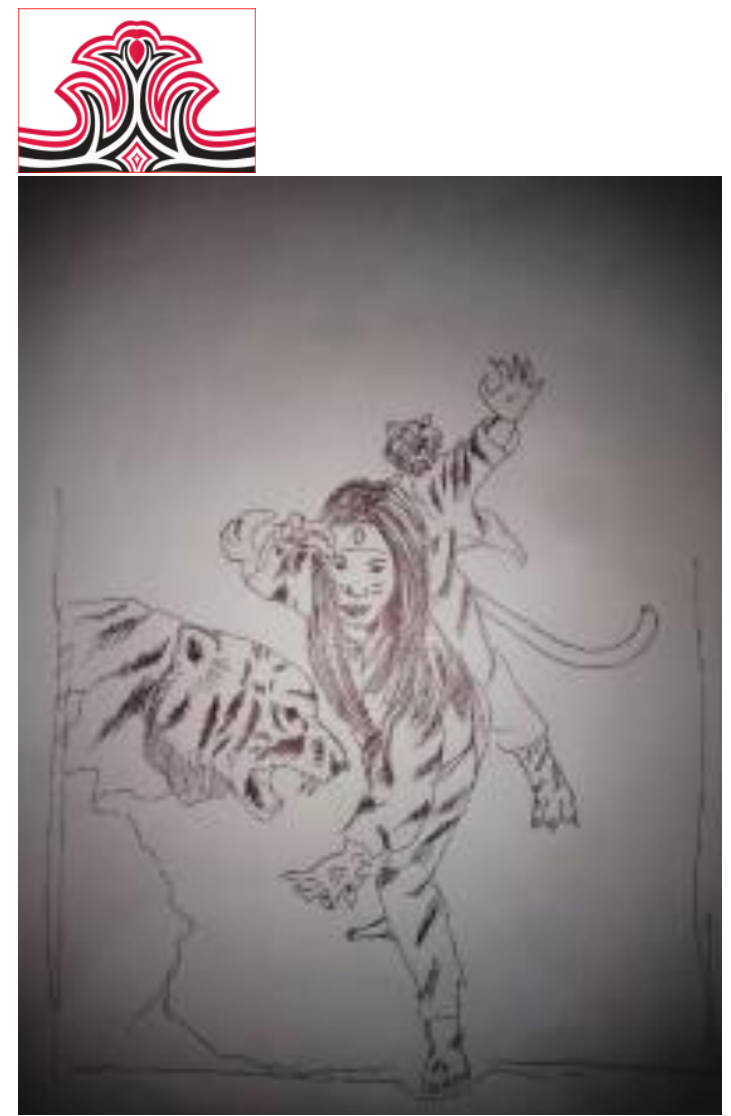

Gambar 12.

Matai Ateh (Silat Harimau Metah Atas)

(Ikhsan, 2021)

\section{2). Sketsa Terpilih}

terpilih merupakan hasil dari pemilihan sketsa aternatif, dari coretan atau pun ide dari pengkarya yang di cantungkan kedalam kertas ketsa, lalu di evaluasi kembali dari hasil tersebud kemudian di lakukang pemilihan desain-desain dari hasil analisi tersebut, dan dapatlah tujuh sketsa terbaik dari semua sketsa yang ada, Kemudian dilakukan pemulihan desains tersebun menjadi sebuah karya seni lukis surealis.
Gorga : Jurnal Seni Rupa

Volume 10 Nomor 02 Juli-Desember 2021

p-ISSN: 2301-5942 | e-ISSN: 2580-2380

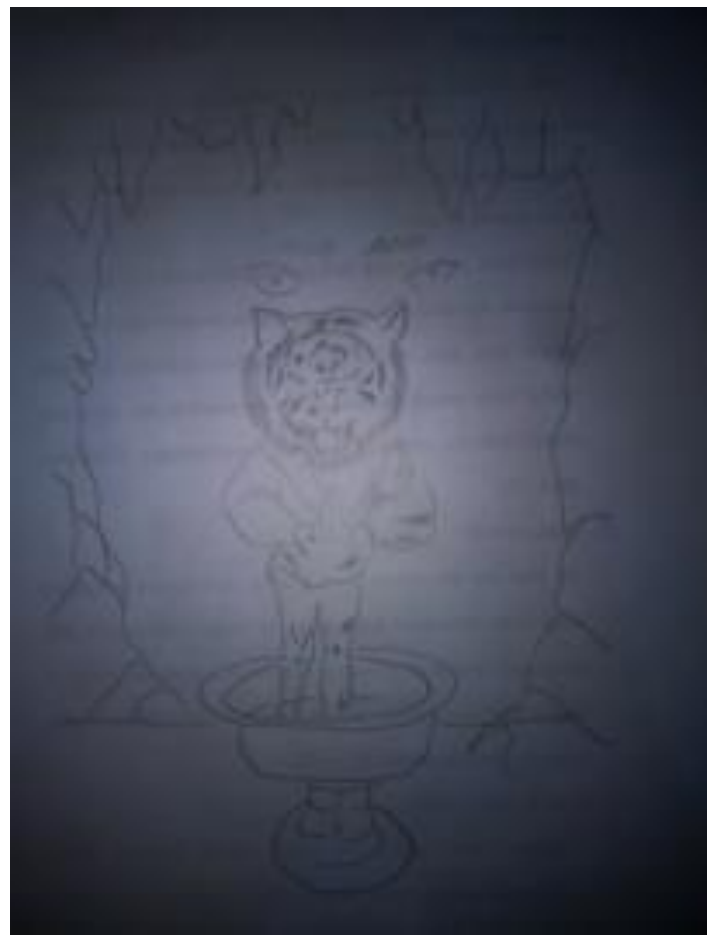

Gambar 13.

Sketsa Terpilih I

(Ikhsan, 2021)

Dari berbagai sketsa artenatif diatas dapatlah sketsa terpilih satu yang berjudul Gerak Pembuka, gerakan ini adalah gerakan yang awal yang di tampilkan pada suatu ritual Mengagah Harimau.

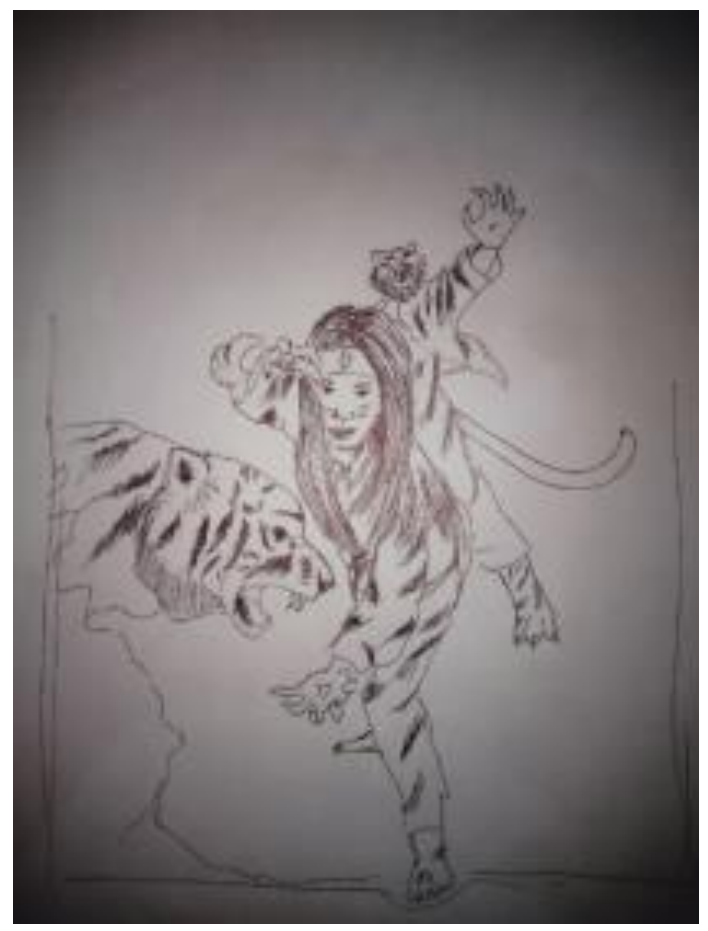

Gambar 14.

Sketsa Terpilih II

(Ikhsan, 2021)

Pada sketsa terpilih dua ini, yang berjudul Gerak Silat Harimau Matah Atas ini mempunyai gerakan yang 


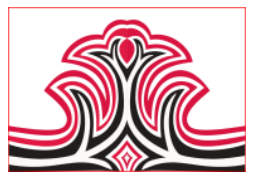

sangat bagus dan mempunyai makna dan simbol yang sangat penting dalam suatu tari Mengagah Harimau, dari struktu dan bentuk yang berbeda namun karya tetepi mempunyai makna yang sana.

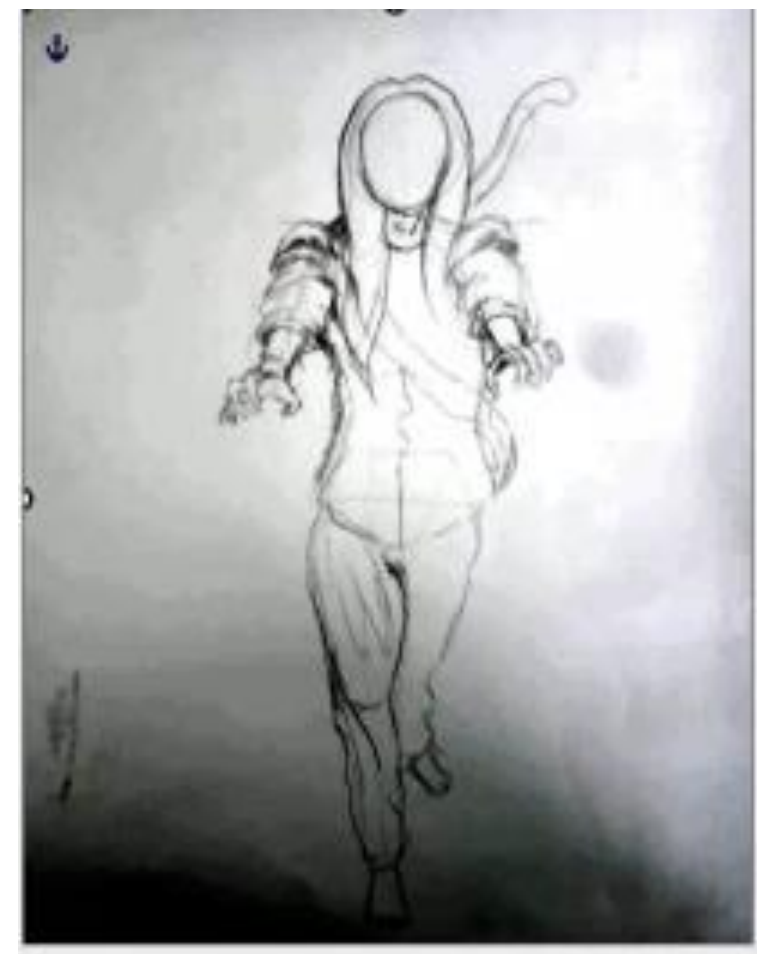

Gambar 15.

Sketsa Terpilih III

(Ikhsan, 2021)

Selanjutnya pada sketsa terpilih ke tiga ini memposisi kan gerak mengagah harimau yang mempunyai sketsa yang sangat menarik menurut pengkarya, dan disaat konsultasi ke pembimbing dan dari hasil wawancara bapak Harun mengatakan dari semua grak tari Mengagah Harimau mempunyai makna yang berbeda, dari beberapa gerakan dapatlah salah satu gerakan ini yaitu gerak Mengagah Harimau.
Gorga : Jurnal Seni Rupa

Volume 10 Nomor 02 Juli-Desember 2021 p-ISSN: 2301-5942 | e-ISSN: 2580-2380

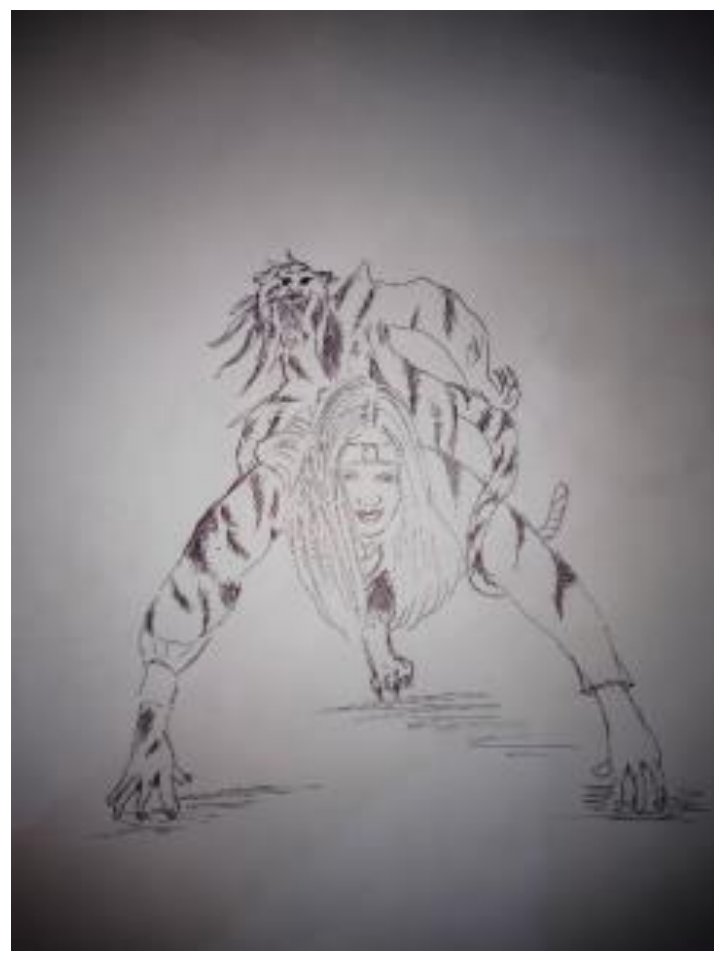

Gambar 16.

Sketsa Terpilih IV

(Ikhsan, 2021)

Seketsa terpilih yang ke empat ini adalah sambungan dari beberapa sketsa terpilih di atas yang ber judul gerak menerkam, gerakan bagian dari gerak-gerak lain nya, tapi mempunyai makna yang berbedan, pada sketsa di atas mengambarkan manusia yang siap menerkam dan dengan sosok harimau,dalam sketsa di atas ada beberapa perbedaan seperti kaki manusia berbentuk kaki harimau yang bisa menjadi dayatarik bagi pengkarya menuju lukukisan surealis. 


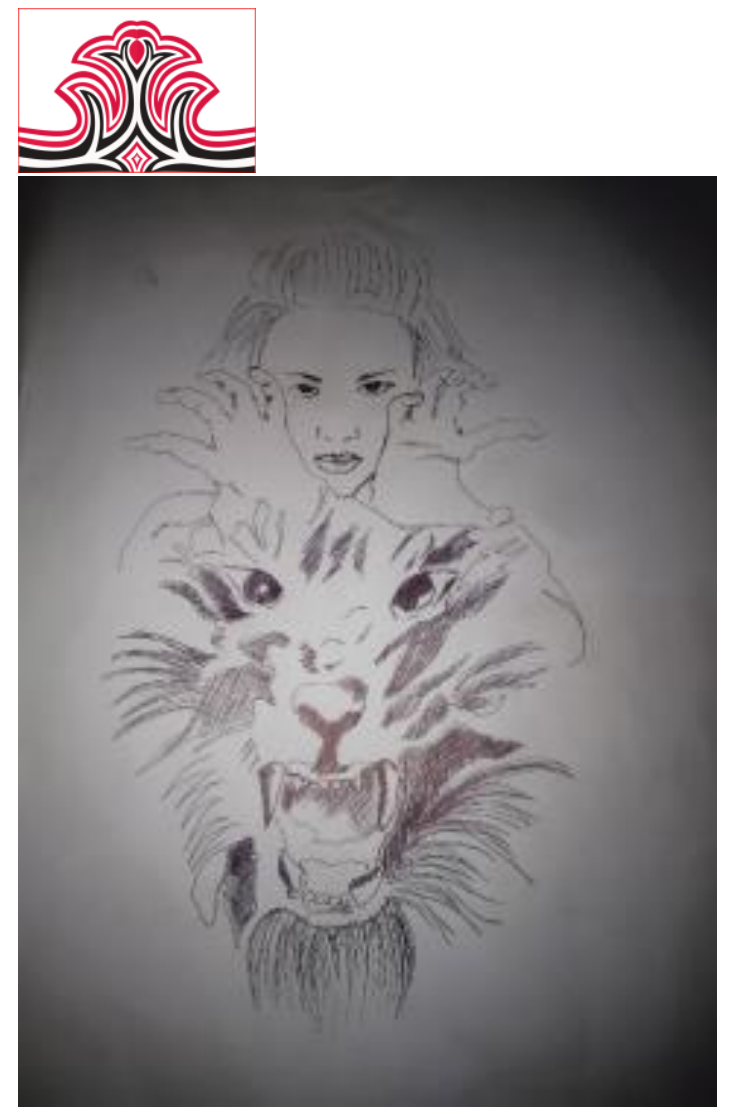

Gambar 17.

Sketsa Terpilih V

(Ikhsan, 2021)

Sketsa terpilih lima ini yang berjudul gerak silang, dalam pemilihan sketsa kelima ini ada beberapa tahap, yang pertama melihat semua sketsa artenatif ke dosen pembimbing dan melakukan wawancara ke narasumber dari beberapa sketsa tari Mengagah Harimau barulah dapat pilihan sketsa terpilih yang kelima ini. Dalam sketsa kelima ini tetap memnggunakan gerak dan di tambahi wajah harimau, dalam sketsa tersebut dapat berbeda dengan gambar aslinya tapi mempunyai makna yang sama.
Gorga : Jurnal Seni Rupa

Volume 10 Nomor 02 Juli-Desember 2021 p-ISSN: 2301-5942 | e-ISSN: 2580-2380

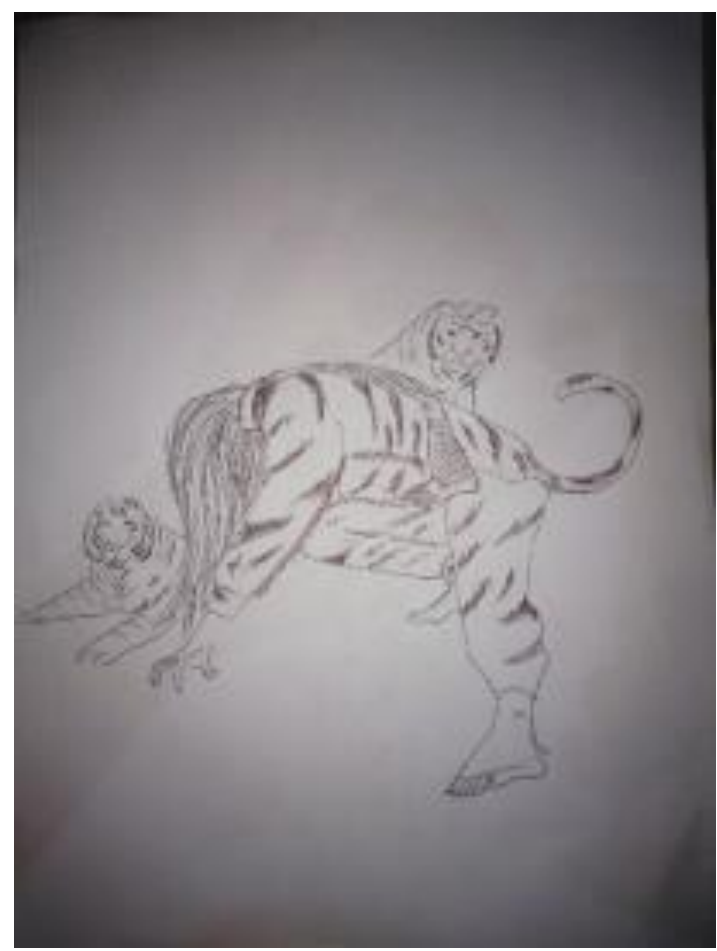

Gambar 18. Sketsa Terpilih VI ((Ikhsan, 2021)

Selanjutnya pemilihan sketsa ke enam ini sama seperti pemilihan sketsa-sketsa sebelumnya, melakukan riset mengalikan makna dari gerakan dari tari Mengagah Harimau kemudian melakukan bimbingan kedosen pembimbing mengenai sketsa tersebut, barulah dapat sketsa terpih ke enam ini. 


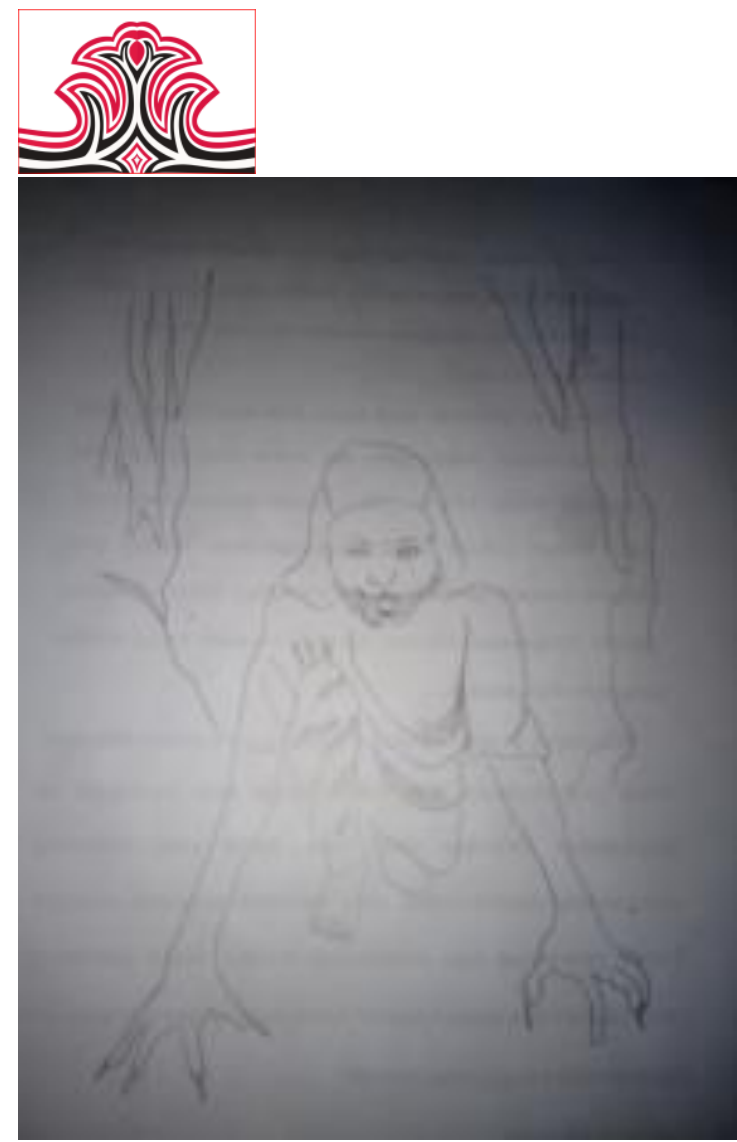

Gambar 19.

Sketsa Terpilih VII

(Ikhsan, 2021)

Sketsa terpilih tujuh ini iyalah hasil dari pilihan sketsa artenatif yang mengambarkan sosok wanita yg bermuka harimau, dari berbagai sketsa artenatif dapatlah pilihan sketsa ke tujuh ini, karena mempunyai gerakan yang sangat bagus, dan mempunyai makna dan pesan dari suatu gerakan dari sketsa tersebut.
Gorga : Jurnal Seni Rupa

Volume 10 Nomor 02 Juli-Desember 2021

p-ISSN: 2301-5942 | e-ISSN: 2580-2380

\section{Pembahasan}

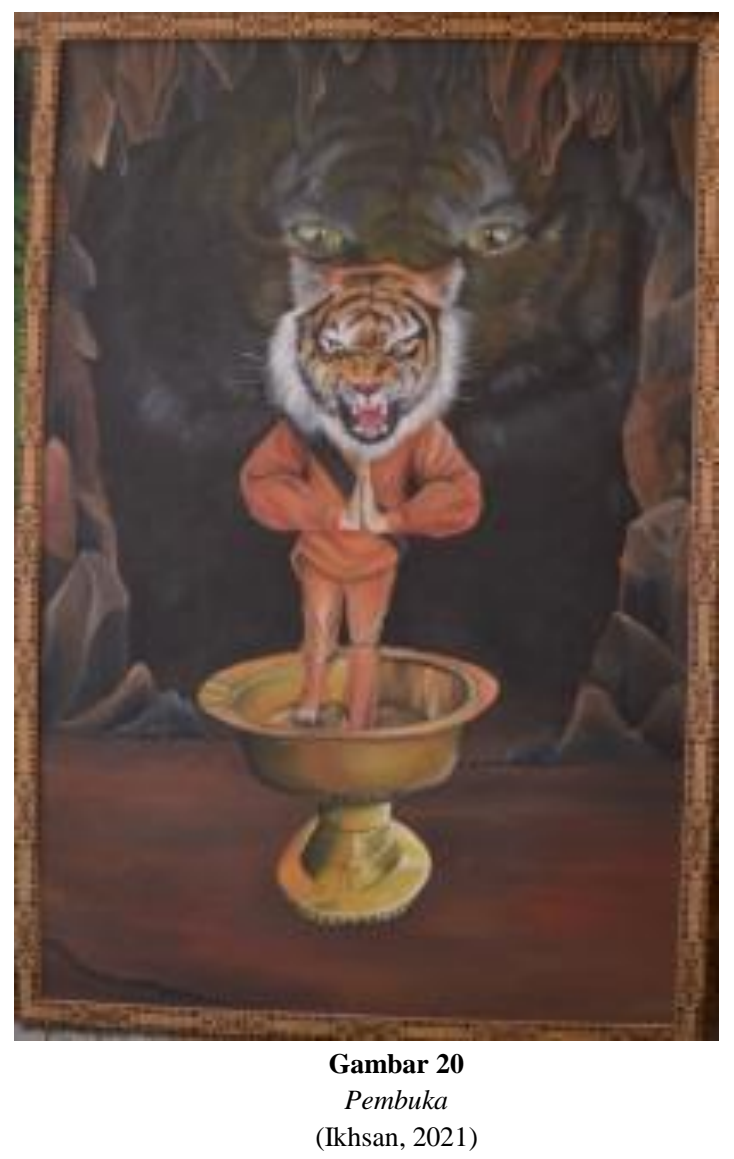

Karya "pembuka" terinspirasi dari tari Mengagah Harimau yang berukuran $90 \mathrm{~cm}$ x $120 \mathrm{~cm}$ dibuat pada tahun 2021. Subjek matter pada karya pertama ini adalah bentuk seorang penari yang menari di atas dapeu kemenyo (carano) dan berbentuk muka harimau. Mengamati seorang penari yang menari dari tarian awal pemanggilaan roh harimau yang di lakukan oleh seorang penari mengagah harimau. Dalam karya pertama ini mengambarkan sosok penari yang sedang memangil roh harimau seolah-aloh harimau yang mulai masuk kedalam jiwa sipenari ditandai dengan sosok penari berkepala harimau dan bayangan harimau. Sedangkan cerano adalah alat pemanggilan roh yang di sebut dengan dapeu kemenyo.

Selain itu penari juga pernah merasakan bagaimana awal dari kemasukan roh harimu, peanari merasakan semua tubuh dari kepala sampai kaki merasa besar, karya yang berbentuk penari yang berujud kepala harimau yang besar, visual latar beakang lukisan mengambarkan sosok seperti roh harimau yang melambangkan ritual sudah dimulai. Komposisi dalam melukis agar lukisan tersebut terlihat seimbang (balance) sehingga saling menunjang atau saling seimbang dalam membangun komposisi pakaian figur perempuan memakai baju Mengagah Harimau yang berwarna orange yang bergaris-garis seperti belang 


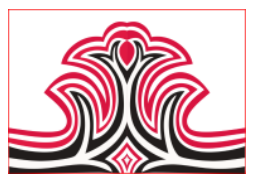

harimau, dari berkarya tersebut dapat menghasilkan garis potus-putus yang berbentuk bayangan harimau. Hal ini merupakan simbol dari awal kedatanga roh harimau yang ingin merasuki sipenari dan penonon yang mempunyai garis keturunan orang pulau tengah.

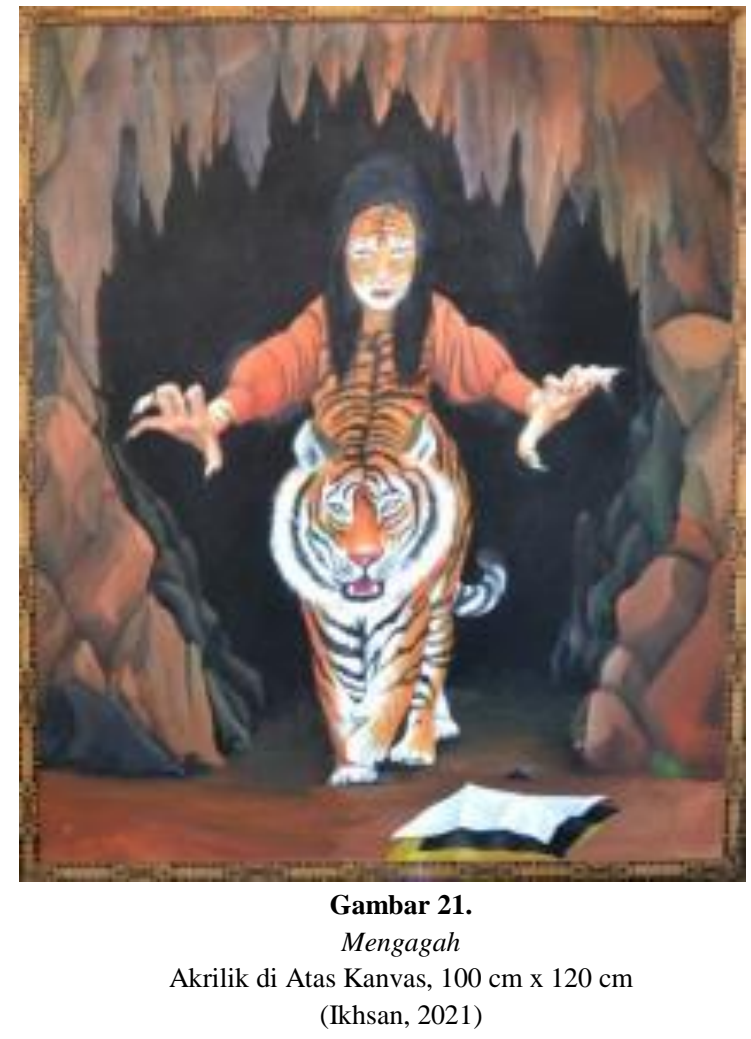

Ngagen imo (mengagah harimau) berukuran 100 x 120 $\mathrm{cm}$, dengan media seni lukis surealis, karya ini menggunakan bahan akrilik di atas kanvas. Karya ke dua ini mengungkapkan perasaan yang dirasakan dalam mengamati ritual mengagah harimau. Karya ini terinspirasi dari Tari Mengagah Harimau, penggarapan karya ini mengambarkan gerakan seorang yang sedang menghibur hariamau yang telah mati, dan diagah seolah-olah hidup di tandai dengan sosok harimau di depan penari yang telah membayar bangun/denda. Ritual ini bertujuan agar harimau yang masih hidup, tidak menganggu warga dan tidak memakan ternak warga pulau tengah kerinci setelah membayar bangun.

Proses penciptaan karya menggunakan teknik sapuan kuas yang sangat halus, untuk menimbulkan gradasi dari pakaian yang sangat tegas, dari objek utama, serta dari proses tersebut yang menghasilkan garis yang tengas. Hal ini merupakan simbol dari masyarakat kerinci yang tengas seperti sosok harimau. Berdasarkan simbol kain tiga warna pada karya ini mengambarkan perjanjian antara harimau, hilang belang diganti dengan belang yang di sibolkan melalui kain.
Gorga : Jurnal Seni Rupa

Volume 10 Nomor 02 Juli-Desember 2021 p-ISSN: 2301-5942 | e-ISSN: 2580-2380

Karya ini memposisikan kedua tangan mencakar kedepan dan badannya agak membungkuk kedepan seolah-olah menerkam selayaknya mengagah harimau yang masih hidup, visual latar belakang karya berbentuk batu-batuan berbentuk goa dan dilambangkan sosok harimau yang berjalan kedepan.

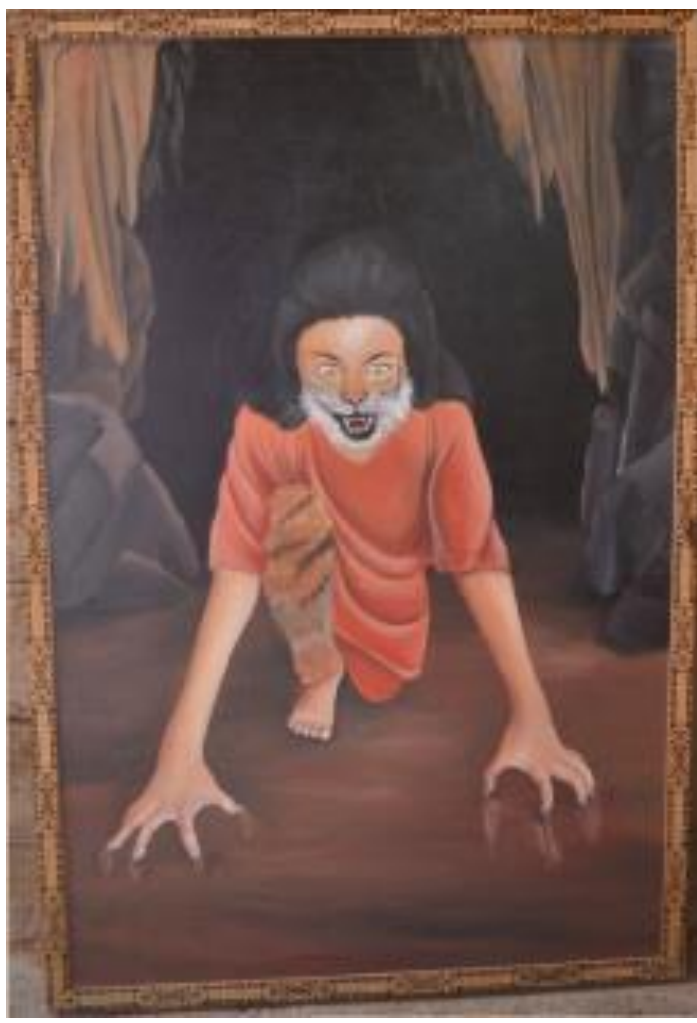

Gambar 22

Grak membela

Akrilik di Atas Kanvas, $80 \mathrm{~cm}$ x $120 \mathrm{~cm}$

(Ikhsan, 2021)

"Membela" yang di buat pada tahun 2021, karya ini dibuat dengan bahan akrilik di atas kanvas yang berukuran 80 x $120 \mathrm{~cm}$. Karya ini mengambarkan orang yang kesurupan seperti hariamau yang siap menerkam, dari lukisan tersebut di amati setiap seorang yang mempunyai garis keturunan dari orang Pulau Tengah Kerinci akan kesurupan, karana mereka merasakan memiliki adat dan memahami syair mantra yang diucapkan oleh pawang Mengagah Harimau. setiap dilakukan Ritual Mengagah Harimau setiap penari atau penonton bisa kerasukan. Biasanya, yang memiliki hubungan darah dari keturunan orang Pulau Pengah Kerinci Jambi dan yang memahami syair lagu matra tari tersebut.

Pada karya ini "membela" menggunakan teknik sapuan kuas yang sangat halus, untuk menimbulkan gradasi dari pakaian yang sangat tengas, dari objek utama yaitu manusia yang berbentuk setengah manusia dan harimau, sedang kan visual latar belakang masih sama seperti karya-karya sebelumnya yang berbentu 


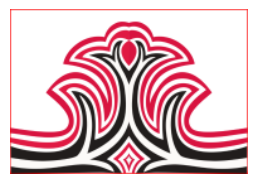

goa yang berbatu seolah-olah singgasana seekor harimau, pada karya ini menerapkan tingkatan warna yang sangat tajam dan dingin, sehingga objek akan tampak nyata. Jari tangan nya membentuk cakaran harimau yang sangat buas, sedang kan posisi tangan kedepan mencakar dan posisi kepala menghadap kedepan. Pada objek lukisan ini di pokuskan pada penari, yang di sesuaikan warna gelap terang pada graperi pakaian menumbulkan unsur dua dimensi yang di wujudkan menjadi lukisan surealis.

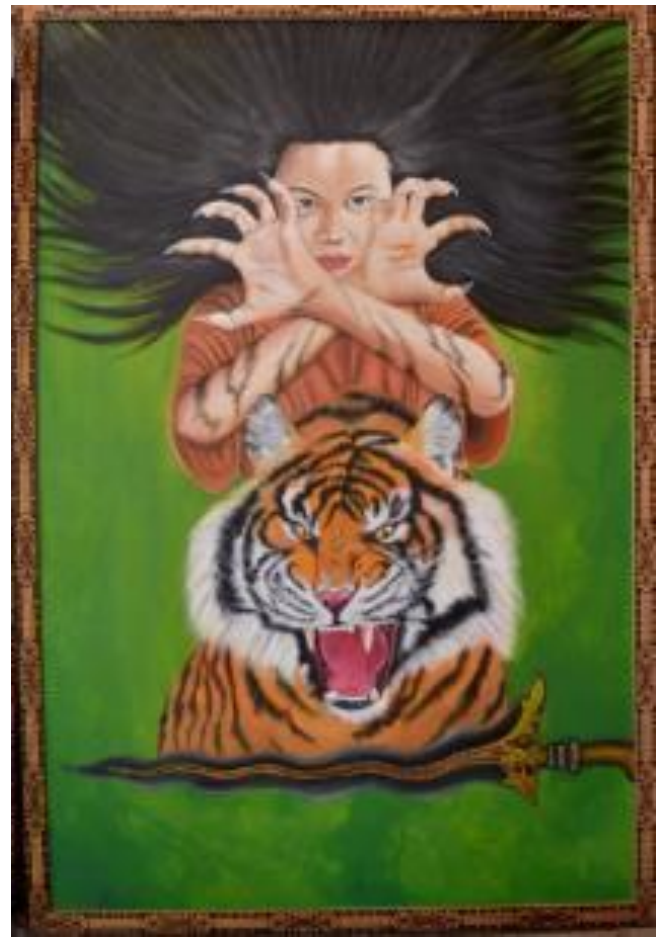

Gambar 23.

Cakar Silang

Akrilik di Atas Kanvas, 90 cm x $120 \mathrm{~cm}$ (Ikhsan, 2021)

"Cakar silang atas" dibuat pada tahun 2021 menggunakan media seni lukis. Karya ini menggunakan bahan akrilik di atas kanvas yang berukuran 90 x $100 \mathrm{~cm}$. pada karya ini mengungkapkan apa yang di lihat dan apa yang di rasakan melalui karya ke empat ini. Pada karya ini mengekspresikan berbentuk seorang yang mencakar silang dan didepan nya harimau dan keris sebilah, keris sebilah di simbolkan dengan pergantiyan taring, dari karya ini menyampaikan pesan yang sangat penting, harapan nya dengan ritual ini tidak ada silang sengketa antara harimau dan masyarakat pulau tengah setelah membayar bangun/denda. Dan tidak saling menganggu antar harimau dan manusia.

Warna pakaian tetap sama dengan karya yang sebelumnya sedangkan visual latar belakang yang beda yang berwarna hijau melambangakan hutan yang
Gorga : Jurnal Seni Rupa

Volume 10 Nomor 02 Juli-Desember 2021 p-ISSN: 2301-5942 | e-ISSN: 2580-2380

hijau dan sejuk yang dikuasai titisan nenek moyang yaitu sosok harimau, pada objek utama mengambarkan wanita yang bermuka sangar dan tangan cakar menyilang dan sosok harimau yang mengaum, pada tahap pembuatan karya ini mengunakan sapuan kuas yang sangat halus di atas kanvas sehingga menimbulkan kesan yang sangat menarik.

Pada karya menampilkan keris sebilah yang simbol penganti taring dengan keris sebilah, seolah olah-olah harimau hidup yang dibayar bangun yang dibaca oleh pawang, hilang blang di nganti kain tiga warna dan hilang kuku diganti dengan keris sebilah, karna dipercay dari leluhur sejak dahulu, hilang belang ganti dengan kain tiga warna, hilang taring diganti dengan keris, hilang suara dinganti dengan gong.

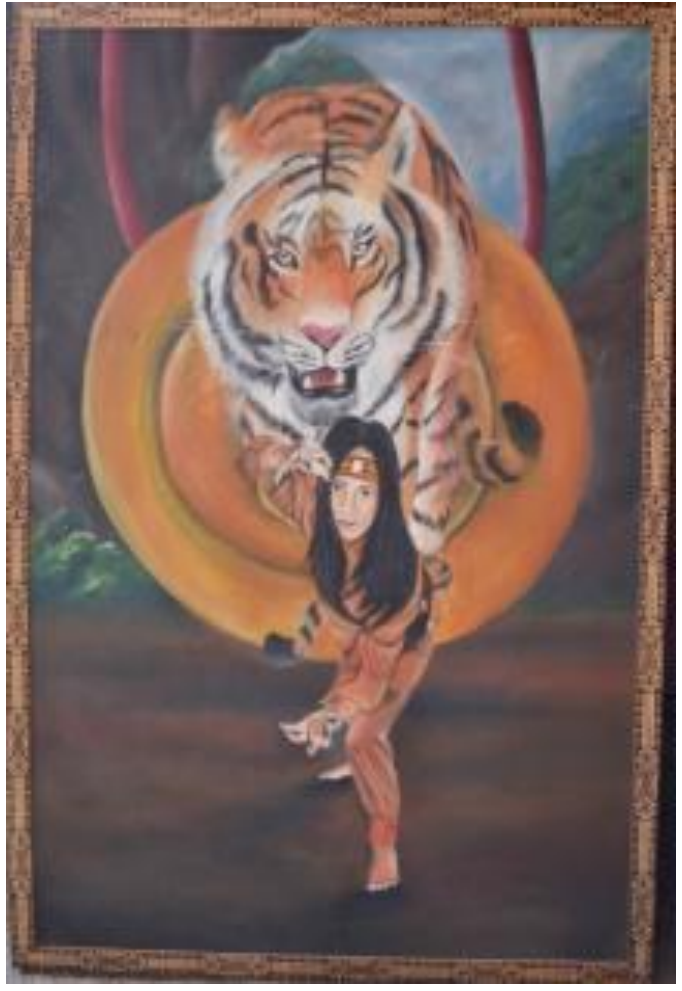

Gambar 24.

Ngko Matai Ateh

Akrilik di Atas Kanvas, $90 \mathrm{~cm}$ x $120 \mathrm{~cm}$

(Ikhsan, 2021)

Matai Ateh (mematah atas) Karya ini menggunakan bahan akrilik di atas kanvas, karya dibuat pada tahun 2019 berukuran 90 X $120 \mathrm{~cm}$. Matai ateh (patah atas) mengungkapkan prasaan yang di cantum ke dalam karya ke kelima ini menampilkan sosok wanita mencakar kedepan seperti mematah di atas terinspirasi dari panca silat yang di gunakan dalam tari mengagah harimau, dan di belakang di dukungi sosok harimau yang buas dan di dukungi dengan gong yang tergantung di belakang harimau menyimbolkan suara auman harimau. Keseluruhan karya ke lima ini 


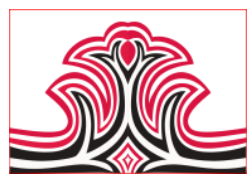

menyampaikan pesan kepada manusia, jangan pernah menggagu habitat kami dan janganlah membinasakan kami yang terdengan dari auman harimau yang di makna dengan gong.

Pembuatan karya ini menambah unsur Penekanan atau kontras adalah prinsip yang mendasari kesan perbedaan dari dua unsur yang berlawanan dan saling berdekatan. Penekanan akan membuat sebuah karya ini tidak bersifat monoton. Dengan memberikan perbedaan yang mencolok pada bentuk, warna, dan ukuran sebuah karya ini akan terlihat lebih menarik.

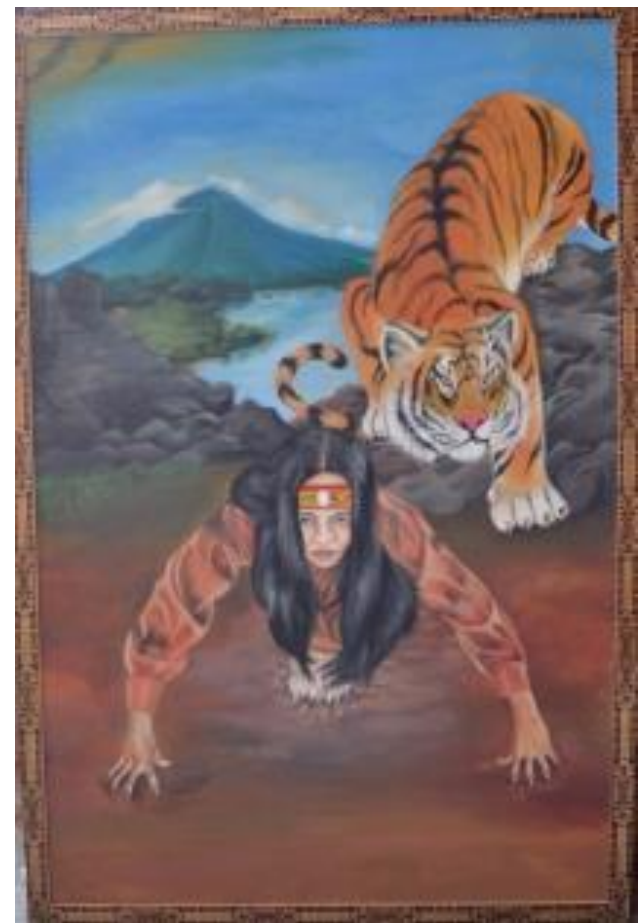

Gambar 25.

Ngko Nak Nepo

Akrilik di Atas Kanvas, $90 \mathrm{~cm}$ x $120 \mathrm{~cm}$

(Ikhsan, 2021)

Karya enam yang berjudul "ngko nak nepo" di buat pada tahun 2021 menggunakan media seni lukis. Karya ini menggunakan bahan akrilik di atas kanvas yang berukuran 90x100cm. Nak nepo (siap menerkam) karya ke enam ini menyimbolkan seorang yang siap menerkam selayaknya harimau yang ditandai dengan kaki yangg sangat besat menekan ketanah yang di dukung dengan sosok harimau yang sangat buas. Pada latar belakang terlihat gunung yang berwarna belang harimau yang di artikan dengan habitat harimau dan junga menjadi aikon asli Kerinci yaitu gunung Kerinci. Karya ini juga menampilkan harimau yang turun gunung yang ingin merasuki penari dan penonton dari keturunan orang Plau Tengah. Karya ini menyampaikan pesan kepada masyarakat kerinci bahwa jangan pernah menganggu kawasan kami dan
Gorga : Jurnal Seni Rupa

Volume 10 Nomor 02 Juli-Desember 2021 p-ISSN: 2301-5942 | e-ISSN: 2580-2380

jangan pernah menganggu kami dan kami tidak akan menganggu kalian.

Posisi badan gerakan ini merunduk dan kaki kiri dan kanan mundur kebelakang sehinga badannya condong kedepan dan kedua tangannya mencakar kedepan seolah-olah sedang siap menerkam, pada karya ini dapat dilihat pada visual utama secara keseluruhan terdapat beberapa objek yang sangat menarik yang di isi dengan beberapa bentuk seperti latar belakang, yang mengambarkan aikon kerinci seperti gung kerinci, di setiap karya tersebut yang telah di distorsi dari sebuah batu-batuan dan tumbuhan.

Goresan kuas yang halus dan terlihat lebih tajam dan diberi kontur warna yang tebal, dan pada objek lukisan ini juga memakai kain yang sama pada karyakarya lain, fokus cahaya berasal dari area kiri objek yang di sesuaikan, warna gelap terang, pada graperi pakaian yang akan menimbulkan kesan dua dimensi. Dalam karya ini pengkarya junga memasuki komposisi menjadi prinsip yang paling penting dalam mendasari keindahan. Sedangkan tekstur yang halus pada setiap bagian permukaan kulit penari menambah nilai estetis dalam pandangan visual seni lukis surealis.

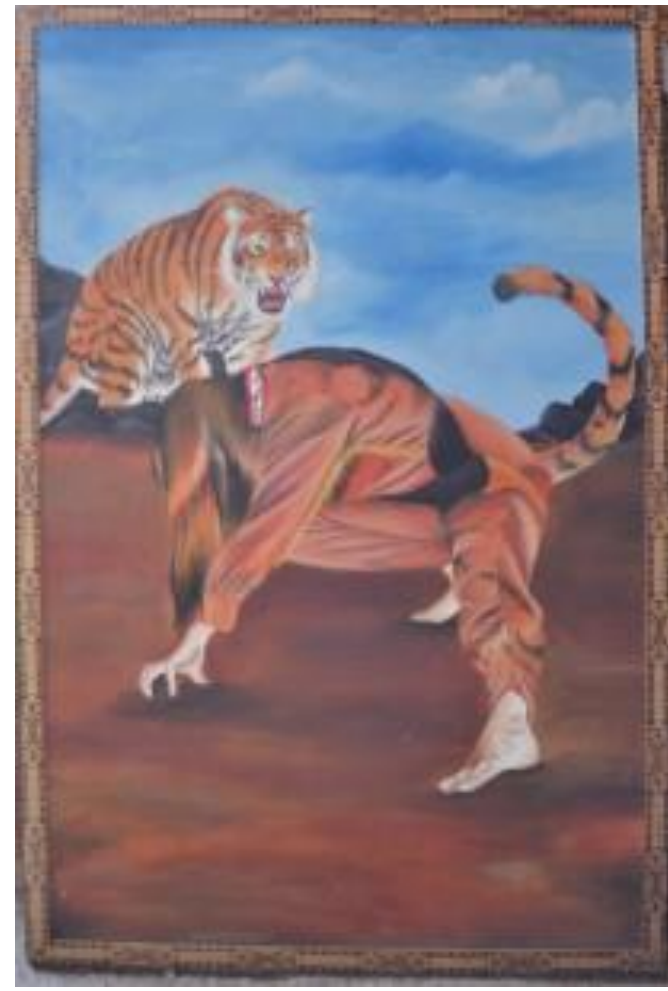

Gambar 26.

Uho Kemasukan Imo

Akrilik di Atas Kanvas, $100 \mathrm{~cm}$ x $120 \mathrm{~cm}$

(Ikhsan, 2021) 
Uho kemasukan imo (orang kerasukan roh harimau) dibuat pada tahun 2019 berukuran 100 X120 cm. memvisualisasikan Karya ini dengan menceritakan bentuk seorang yang kerasukan roh harimau yang mempunyai darah keturunan dari masyarakat Pulau Tengah yang mempunyai perjanjian dengan harimau dari leluhur mereka. Dengan adanya ritual ini diyakini bahwa roh harimau akan mendengar dan datang menjelma, karena harimau mempunyai kuping tanah, yang ingin menyapaikan pesan bahwa apa yang di bayar sudah tersampai dan sudah di terima antara manusia dan harimau.

Karya ini berposisiskan penari yang kerasukan roh harimau yang turun dari gunung kerinci yang merasuki tubuh sipenari, yang memposisiskan tubuh yang kesamping menunduk kebawah mencakar dan mengeluarkan suara,dari kepercayaan masyarakat Pulau Tengah Kerinci, yang memasuki tubuh si penari iyalah nenek moyang yang menjaga hutan dan cucu yang berada di desa.

Pada visualisasi warna tetap seperti warna-warna karya yang telah dibuat oleh pengkarya di karya sebelumnya. Pencahayaannya dari depan sebelah kiri ke arah kanan, sedangkan pengulangan yang dilakukan secara bervariasi akan menghasilkan irama harmonis yang dapat meningkatkan nilai estetika dari karya seni yang dibuat.
Gorga : Jurnal Seni Rupa

Volume 10 Nomor 02 Juli-Desember 2021

p-ISSN: 2301-5942 | e-ISSN: 2580-2380

\section{KESIMPULAN DAN SARAN}

\section{Kesimpulan}

Mengagah Harimau: Ritual Budaya Masyarakat Pulau

Tengah Kabupaten Kerinci merupakan prosesi adat yang digunakan dalam setiap ada harimau yang mati di hutan atau mati di bunuh, maka di laksanakanlah ritual mengagah harimau. Ritual Mengagah Harimau mengandung pesan dan makna dalam ritual tersebut, pada pelaksaan dalam ritual Mengagah Harimu menginterpretasikan harapan agar harimau yang masih hidup tidak turun gunung dan tidak menggu ternak warga Pulau Tengah Kerinci. Dari ritual tersebut pengkarya ingin mengenalkan ritual Mengagah harimau dalam bentuk baru melalu seni lukisan surealis. Bentuk visual yang di angkat masing-masing dalam Mengagah Harimau dalam lukisan surealis diantaranya, 1). Pembukak, 2). Mengagah, 3). Membela, 4). Cakar Silang, 5). Matai Ateh, 6). Uho Nak Nepo, 7). Uho Kemasukan Imo.

Karya ritual Mengagah Harimau ini di aplikasikan kedalam karya lukis surealis merupakan karya dua dimensi yang bersifat lukisan, yang mementingkan nilai keindahan pemaknaan dan nilai kertarikan pada penikmat seni dan masyarakat yang melihat lukisan Mengagah Harimau dalam bentuk lukisan surealis.

\section{Saran}

Dalam membuat suatu karya seni tentunya membutuhkan suatu dukungan serta pengalamampengalaman yang dapat dijadikan suatu pelajaran. Melakukan pendekatan-pendekatan terhadap apa yang akan menjadi objek visual adalah suatu cara untuk mengenal lebih dalam tentang krateristik dari sebuah bentuk-bentuk visual objek yang akan ditampilkan. Haltersebut sangatlah tidak mudah, sehingga dibutuhkan pengamatan yang ekstra untuk dapat menyajikan karya-karya gerak tari tradisi yang telah menjadi konsep pokok dalam proses penciptaan.

Kendala dalam berkarya Mengagah Harimau tentu menjadi tantangan yang perlu di atasi. Dalam mengerjakan karya ini memakan durasi waktu yang singkat dan tingkat kerumitan dalam menciptalan desain sangatlah rumit, karena didalam menciptakan sebuah desain perlu di wujudkan pemikiran atau ide yang sangat teliti dan pengkarya harus menentukan ukuran desain, tata letak objek, simbo, yg ingin di tuangkan ke kanvas dengan waktu yang singkat agar pekerjaan dalam berkarya apat terselesaikan tepat waktu. Proses pelaksanaan berkarya melakukan teknik lukisan surealis yang di tekuni dalam perkuliahan agar mampu di kuasai dalam berkarya. 
DAFTAR RUJUKAN

Couto, Nasbahry. (1999), Gaya Dalam Seni Rupa Pemahaman Bahasa Seni Rupa Modern. Padang: Jurusan Seni Rupa FBSS Univeristas Negeri Padang.

Halawa, W. E., Triyanto, R., Budiwiwaramulja, D., \& Azis, A. C. K. (2020). Analisis Gambar Ilustrasi Hombo Batu Nias Gunungsitoli. Gorga: Jurnal Seni Rupa, 9(1), 193-203.

Ikhsan, Al. (2021). "Mangagah Harimau". Hasil Dokumentasi Pribadi: 4 Februari 2021, Kerinci.

Kartika, Dharsono Sony, (2016). Kreasi Artistik. Karanganyer. Surakarta: UNS.

Prabu, W. N. D. (2017). Imaji Pop Surealisme Figur Gendut Dalam Lukisan. Journal of Urban Society's Arts, 4(1), 36-48. 